\title{
Antropogeneza i jej związek z ewolucją wszechświata w teilhardyzmie
}

\begin{abstract}
Wstęp
Teilhard de Chardin wielokrotnie stwierdzał, iż jego poglądy nie stanowią zamkniętego systemu filozoficznego. On sam traktował je bardziej jako sugestie, niż definitywne rozwiązania różnych problemów. Chodziło mu raczej o otwarcie przed ludźmi nowych horyzontów myślowych i pobudzenie ich do szerszego spojrzenia na rzeczywistość. Autora „Fenomenu człowieka” szczególnie interesowała antropologia, zarówno przyrodnicza, jak filozoficzna i teologiczna. Jako że był on nie tylko kapłanem katolickim, lecz także naukowcem (paleontologiem i geologiem) dlatego jego postawa intelektualna nie powinna budzić zdziwienia. Francuski jezuita koncentrował swoją uwagę badawczą przede wszystkim na człowieku ujętym jako gatunek, a nie indywidualna osoba ludzka i analizował go łącznie $z$ wszechświatem podlegającym procesowi ewolucji zbieżnej. Z tego powodu gatunek ludzki jest, jego zdaniem, organicznie związany z kosmosem jako ze środowiskiem, w którym dokonuje się jego rozwój. Człowiek w doktrynie Teilharda okazuje się więc istotą, której ostateczne spełnienie związane jest z sukcesem procesu ewolucji kosmicznej. Jednocześnie francuski myśliciel uznał, iż dokładne poznanie fenomenu ludzkiego pozwoli na zrozumienie całej rzeczywistości. W jednym z esejów stwierdził: „Człowiek zajmuje w świecie pozycję kluczową, biegunową, wyznaczającą główną oś świata. Wystarczyłoby zrozumieć człowieka, by zrozumieć wszechświat. Obraz wszechświata byłby niezrozumiały, gdyby się w nim nie mieściło w sposób logiczny wszystko, co wiemy o człowieku." Tak ścisła zależność istnienia i rozwoju gatunku ludzkiego od procesu ewolucji wszechświata skłania do ujmowania antropologii Teilharda jako antropogenezy oraz zmusza do analizowania jej w kontekście całego systemu teilhardowskiego opisującego kosmiczną ewolucję zbieżną.
\end{abstract}

Teilhard de Chardin, Pisma, t. 1, s. 13. 


\section{Proces ewolucji wszechświata według Teilharda de Chardin}

Teoria ewolucji, która najpierw pojawiła się w naukach przyrodniczych, stała się z czasem przyczyną zmiany paradygmatu w pozostałych dyscyplinach naukowych i spowodowała zdynamizowanie wizji świata. Oprócz ewolucjonizmu biologicznego pojawił się także ewolucjonizm uogólniony, filozoficzny, który streszcza się w poglądzie, iż cała rzeczywistość podlega nieustannym zmianom, a wszelkie byty powstają wyłącznie w wyniku ewolucyjnego procesu rozwojowego. Na terenie filozofii do grona najbardziej znanych ewolucjonistów należeli m.in.: Georg Wilhelm Friedrich Hegel, Karol Marks, Herbert Spencer oraz Henri Bergson. Myślicielem podzielającym poglądy ewolucjonistyczne był także Teilhard de Chardin, który głosił ewolucję kosmiczną, a jeden z jej aspektów stanowi ewolucja biologiczna dotycząca rozwoju organizmów żywych, w tym również człowieka. Poglądy Teilharda najbardziej przypominają koncepcję Henri Bergsona, według której ewolucja przebiega nie tylko w sferze materialnej, lecz także w sferze duchowej i jest ze swej natury twórcza. Zdaniem francuskiego jezuity jest to w przyrodzie ożywionej ewolucja progresywna, zaczynająca się od tzw. przedżycia (previé), wiodąca przez życie komórek, roślin i zwierząt aż do człowieka. Teilhardyzm daje też pewien całościowy obraz rzeczywistości używając do tego celu koncepcji ewolucji kosmicznej. Idea ewolucji zbieżnej wszechświata zmierzającego od stanu jego nieuporządkowanej (materialnej) wielości do wewnętrznej (duchowej) jedności i zjednoczenia z Bogiem zyskała w efekcie rangę zasady ontologicznej. Według francuskiego myśliciela nie jest ona tylko teorią naukową, lecz realnym, doświadczalnie stwierdzanym procesem. Prawu ewolucji kosmicznej podlegają zaś nie tylko poszczególne elementy rzeczywistości, lecz również kosmos jako całość. Koncepcja kosmicznej ewolucji zbieżnej jest według Teilharda fundamentem dla wszelkich hipotez naukowych i stanowi nowy paradygmat, na którym należy budować teorie przyrodnicze lub filozoficzne. Francuski jezuita tak oto ujął swoje stanowisko w tej kwestii: „Wierzę, że wszechświat jest ewolucją. Wierzę, że ewolucja zmierza ku duchowi. Wierzę, że duch osiąga spełnienie w osobach. Wierzę, że najwyższą Osobą jest Chrystus Wszechświata." Jest to swoiste filozoficzno-teologiczne wyznanie wiary autora, którego treścią był on dogłębnie przejęty i którego wyjaśnianiu poświęcił całe swoje życie naukowe.

W ujęciu Teilharda prawa ewolucji nie należy utożsamiać z jakąś konkretną teorią przyrodniczą bądź filozoficzną. W jego opinii oznacza ono, że wszechświat to fenomen czasoprzestrzenny będący w nieustannym ruchu, podlegający procesowi rozwoju wiodącego ku jego ostatecznej doskonałości, czyli duchowej pełni oraz wewnętrznej jedności. Ewolucja jest wyrazem zasady, iż nic nowego

Teilhard de Chardin, Pisma, t. 2, s. 17. 
nie może pojawić się w rzeczywistości w inny sposób jak tylko przez ewolucyjne przemiany tworzywa wszechświata. U źródeł ewolucji tkwi - wpisana w rzeczywistość przez Boga - kosmiczna energia miłości współdziałająca z Nim w ciągłym stwarzaniu bytów (analogia do augustyńskiej koncepcji creatio continua - nieustannego Bożego aktu stwórczego, podtrzymującego świat w istnieniu). Proces tych zmian według francuskiego filozofa posiada pewien określony kierunek i cel. Powyższy pogląd różni Teilharda od grupy ewolucjonistów, którzy opowiadają się za bezcelowością ewolucji. Całość ewolucyjnych przemian rzeczywistości zmierza ku Bogu, zwanym w teilhardyzmie punktem Omega, a poszczególne etapy ewolucji stanowią następujące jej fazy:

1) Kosmogeneza - stopniowe powstawanie wszechświata z tworzywa kosmicznego.

2) Geogeneza - kształtowanie się Ziemi.

3) Biogeneza - powstanie i rozwój życia organicznego.

4) Psychogeneza - pojawienie się prostego psychizmu, zwłaszcza zwierzęcego.

5) Antropogeneza - kształtowanie się człowieka jako gatunku o świadomości refleksyjnej.

6) Noogeneza - organizacja sfery wspólnej myśli ludzkiej (noosfery).

7) Chrystogeneza - zjednoczenie ludzkości z Chrystusem Wszechświata.

8) Teogeneza - odwieczne rodzenie się jednego Boga w troistości Osób. ${ }^{3}$

Kosmos jako całość ewoluuje, a podłożem ewolucji, jej substratem, jest tworzywo wszechświata (letoffe d’univers). Teilhard pragnął przezwyciężyć dualizm ontyczny ducha i materii, dlatego przyjął, iż ów substrat jest duchomaterią, czyli tworzywem posiadaiącym jednocześnie właściwości materialne i duchowe. Jego zdaniem duch i materia są dwoma przejawami owego tworzywa, gdy badamy je empirycznie. Do opisu duchomaterii francuski myśliciel używał również pojęcia substancja substancji, przez którą rozumiał najpierwotniejszy i najbardziej wewnętrzny element budujący wszelkie byty oraz terminu substancji niedopetnionej, czyli tworzywa, które musi ewoluować, aby dojść do swej pełnej doskonałości. ${ }^{4}$ Ewolucja tworzywa wszechświata prowadzi do coraz większej jej spirytualizacji, czyli przemiany w ducha i wyłaniania się myśli- najpierw prostej, np. zwierzęcej, a wreszcie także ludzkiej świadomości refleksyjnej. Materialny aspekt duchomaterii traci z czasem swoje kluczowe znaczenie na rzecz jej aspektu duchowego. Teilhard określał owe dwa przejawy tworzywa wszechświata mianem oblicza zewnętrznego (materia) i wewnętrznego $(d u c h){ }^{5}$ Pisząc o wnętrzu bytów francuski jezuita

\footnotetext{
Por. Cz. Bartnik, Teilhardowska wizja dziejów, Lublin 1975, s. 19.

4 Por. Cz. BART NIK, Problem historii uniwersalnej w teilhardyzmie, Lublin 1972, s. 32.

5 Por. Teilhard de Chardin, Pisma, t. 4, s. 20.
} 
miał na myśli nie tylko psychikę typu zwierzęcego lub ludzkiego, lecz także rudymentarne jego formy (tzw. prepensé) obecne w każdym elemencie wszechświata, chociaż niedostępne empirycznej obserwacji naukowej. Owe zalążki psychizmu są, zdaniem Teilharda, współrozciągłe z materią i noszą one także nazwę energii radialnej (w odróżnieniu od energii tangencjalnej, stanowiącej przedmiot fizyki). ${ }^{6} \mathrm{~W}$ związku z tym poglądem można doszukiwać się $\mathrm{w}$ doktrynie teilhardowskiej pewnych analogii do panpsychizmu, czyli nauki o psychicznym (duchowym) charakterze rzeczywistości. Francuski paleontolog twierdził, iż w swej twórczości naukowej nie stosuje twierdzeń ani kategorii metafizycznych, a to, co opisuje, dotyczy wyłącznie zjawisk. Wydaje się jednak, iż zagadnienia takie jak duchomateria lub prymat ontyczny ducha nad materią i preegzystencja zarodków psychizmu w świecie są już tezami metafizycznymi.

Według autora „Fenomenu człowieka” analizowanie tworzywa wszechświata we fragmentach możliwe jest w zasadzie tylko jako zabieg czysto myślowy. W rzeczywistości bowiem stanowi ono nierozerwalną całość. Im bardziej się je dzieli, tym bardziej ukazuje swoją wewnętrzną jedność polegającą na podobieństwie budujących je elementów. Okazuje się, iż kosmos stanowi integralny i nierozerwalny system (sieć), w którym każdy z jego składników związany jest (przynajmniej potencjalnie) ze wszystkimi pozostałymi. Proces ewolucji prowadzi do postępującej spirytualizacji tworzywa wszechświata i stanowi swego rodzaju genezę ducha $\mathrm{z}$ materii. $\mathrm{W}$ trakcie ewoluowania materia i duch tracą cechy przeciwstawności, a duch z czasem przejmuje kontrolę nad tworzywem kosmicznym i zyskuje coraz większe znaczenie. Chociaż to duch kieruje rozwojem materii i sprawia, że podlega ona swoistej sublimacji w duchową myśl, tym niemniej materia jest także niezbędna duchowi do istnienia jako jego podłoże. Obecność duchowej sfery wszechświata jest bowiem wprost proporcjonalna do wielkości jej materialnej podstawy.7 Teilhard w oparciu o teorię zbieżnej ewolucji kosmicznej podjął próbę pojednania materializmu ze spirytualizmem i chciał uniknąć ich dualistycznego traktowania, tak silnie zakorzenionego w filozofii od czasów Kartezjusza. W doktrynie teilhardowskiej duch jest więc fenomenem tak samo jak materia, a nie metafenomenem lub epifenomenem. Jest on też transmaterią, nie zaś antymaterią, czy ekstramaterią. ${ }^{8}$ Spirytualizacja rzeczywistości dokonuje się poprzez swoiste przebycie materii przez ducha i jego stopniowe wynurzanie się z niej. ${ }^{9}$ Ostateczną osnową rzeczywistości jest więc duch, który kieruje przemianą tworzywa wszechświata od stanu rozproszenia do wewnętrznego zjednoczenia (interioryzacji). Początki ewolucji to całkowita, nieuporządkowana wie-

\footnotetext{
Por. Teilhard de Chardin, Pisma, t. 3, s. 170-173.

Por. Teilhard de Chardin, Pisma, t. 1, s. 121.

Por. Teilhard de Chardin, Pisma, t. 1, s. 155.

9 Por. Teilhard de Chardin, Pisma, t. 2, s. 127.
} 
lość wszechświata tożsama z nicością. Teilhardowska koncepcja nicości nie jest zgodna z chrześcijańską nauką o nicości absolutnej, z której Bóg stworzył świat, a przypomina raczej teorię chaosu z mitologii greckiej. Ta właśnie chaotyczna wielość tworzywa kosmicznego jest podatna na tworzenie z niej nowych bytów na drodze ewolucyjnego jednoczenia. Zdaniem francuskiego jezuity byt może być uznany za istniejący nie ze względu na akt istnienia, lecz z powodu swej bytowej jedności. ${ }^{10}$ Zgodnie z teilhardowską nauką o ewolucji kosmicznej zmianom podlegają nie tylko poszczególne byty, ale również samo tworzywo wszechświata. Eschatologicznym kresem procesu ewolucji będzie natomiast całkowita jedność wszystkich elementów kosmosu i połączenie go z Bogiem - punktem Omega. Ewolucja świata według doktryny teilhardowskiej jest zatem ukierunkowana i dzieli się na pewne etapy, określane przez francuskiego myśliciela jako: przedżycie, życie, myśl. Wszystkie te etapy dokonują się na skutek ilościowych oraz jakościowych zmian w tworzywie wszechświata, mających z natury charakter nieciągły. Łączy je natomiast jedno wspólne prawo - tzw. zasada złożoności-świadomości (le loi de complexité-consciance). Prawo to nie tylko pomaga $\mathrm{w}$ opisaniu obecnego stanu rzeczywistości, lecz umożliwia również przewidywanie nawet dalekiej przyszłości kosmosu oraz ludzkości. Zgodnie z nim tworzywo kosmiczne zwija się wewnętrznie, a rozproszona początkowo wielość jego elementów podlega nieustannej syntezie, w wyniku której powstają coraz bardziej skomplikowane systemy materialne, którym z kolei zaczyna towarzyszyć coraz wyraźniej dostrzegalna postać psychizmu. Ów stopniowy wzrost świadomości, aż do fenomenu ludzkiej samoświadomości, towarzyszy zatem kompleksyfikacji materii, czyli coraz większej wewnętrznej złożoności materialnych systemów związanych ze świadomością, zwłaszcza układu nerwowego organizmów żywych. Złożoność danego systemu nerwowego oraz psychizm są więc ze sobą ściśle powiązane genetycznie i strukturalnie. W doktrynie Teilharda termin psychizm oznacza różnorodne zjawiska, często mające niewiele wspólnego z ludzką psychiką. Do jego przejawów francuski uczony zaliczał bowiem zarówno rudymentarne formy świadomości obecne w duchomaterii (które obecnie można by utożsamić ze sferą informacji), jak i prymitywne przejawy psychizmu u jednokomórkowców, czy też wreszcie bardziej złożoną psychikę zwierząt oraz świadomość refleksyjną człowieka. Część tworzywa wszechświata, oprócz ewolucyjnej przemiany w duchową myśl, ulega witalizacji, czyli zapoczątkowuje życie biologiczne. Zdaniem francuskiego jezuity życie w kosmosie także nie jest jakimś przypadkiem lub zjawiskiem wyjątkowym, ale rozwija się ono z zalążków życia (previé - przedżycie) immanentnych tworzywu kosmicznemu i rozwijających $w$ toku ewolucyjnego procesu. Pierwociny życia są więc obecne w całym kosmosie i gotowe do przekształcenia się w różne formy - komórek,

${ }_{10}$ Por. L. WcióRKa, Szkice o Teilhardzie, Poznań 1973, s. 117. 
roślin, zwierząt, gdy tylko znajdą one do swego rozwoju odpowiednie warunki zewnętrzne. Gdy jednak już gdzieś pojawi się życie, to wykorzystuje każdą szansę i rozwija się w stopniu maksymalnym oraz dokonuje ekspansji na jak największym obszarze. Teilhardowska koncepcja zarodków życia tkwiących w duchomaterii przypomina $\mathrm{z}$ jednej strony augustyńską naukę o rationes seminales (racjach zarodkowych) rozwijających się wraz z upływem czasu w poszczególne gatunki organizmów, a $z$ drugiej strony występuje tu analogia ze starożytną teorią hylozoizmu, czyli z uznaniem materii za tworzywo immanentnie obdarzone życiem od początku jego istnienia. Według Teilharda w wyniku ewolucyjnego rozwoju wszechświat jako całość zachowuje tak zwaną energię radialną, tożsamą z psychizmem oraz z życiem, podczas gdy energia tangencjalna, czyli fizyczna, w dużej mierze ulega rozproszeniu na skutek entropii. Francuski paleontolog przyjął także pewną hierarchię, według której byt żywy i świadomy jest doskonalszy od bytu nieożywionego i nieświadomego, zaś bardziej złożona postać psychizmu jest lepsza od jego formy prostszej. Czynnikiem materialnym i empirycznie stwierdzalnym, który wskazuje na poziom osiągniętego psychizmu w danym organizmie, jest $w$ istotach żywych stopień rozwoju ich układu nerwowego, a zwłaszcza mózgu. Zdaniem Teilharda we wszechświecie obecne są zatem trzy rodzaje nieskończoności, gdyż oprócz wielkości nieskończenie dużych oraz małych istnieje jeszcze nieskończona złożoność, z którą wiążą się fenomeny życia i myśli. Pogląd o dążeniu wszechświata w kierunku coraz większej złożoności tworzącej jednocześnie wewnętrzną jedność jest koncepcją szczególnie charakterystyczną dla teilhardyzmu. Dwie pierwsze nieskończoności zauważył i analizował już Pascal, który uznał człowieka za stworzenie rozdarte pomiędzy nimi i zagubione w nieskończonym, obcym wszechświecie. Według Pascala taka tragiczna sytuacja egzystencjalna człowieka możliwa była do przezwyciężenia tylko przez wiarę w Boga wcielonego - Jezusa Chrystusa. Dostrzeżenie przez Teilharda fenomenu nieskończonej złożoności stanowiło dla niego powód do optymizmu nawet z czysto naturalistycznego punktu widzenia, ponieważ wskazywało ono na to, iż świat zmierza ze swej natury ku coraz większej doskonałości. Okazuje się również, że życie i myśl we wszechświecie nie są czymś przypadkowym i nieistotnym, lecz wskazują one na kierunek ewolucji kosmicznej. Francuski myśliciel ową złożoność dążącą do wzrostu duchowości i jedności, tak jak i cały proces ewolucji, uznał ostatecznie za przejaw stwórczej działalności Boga. W jego opinii Bóg jest Bogiem kosmogenezy i posługuje się ewolucją $w$ dziele stwarzania. ${ }^{11}$ Zwieńczeniem ewolucji kosmicznej jest $w$ koncepcji teilhardowskiej pełna przemiana wszechświata w rzeczywistość duchową i połączenie jej z Bogiem - punktem Omega ewolucji, stanowiącym jej przyczynę sprawczą oraz celową. Zdaniem francuskiego jezuity w czasach eschatolo-

11 Por. Teilhard de Chardin, Pisma, t. 1, s. 136. 
gicznych rzeczywistość dopełni się i przemieni przez pośrednictwo Chrystusa Wszechświata w Pleromę, to znaczy w stan doskonałej, duchowej jedności kosmosu, ludzi oraz Boga.

\section{Antropogeneza ewolucyjna w ujęciu Teilharda de Chardin}

Spór o ewolucję rozpoczęty w XIX wieku przez odkrycia oraz dzieła Darwina z biegiem czasu ogarnął nie tylko środowiska naukowe, lecz przeniknął także do szerokich kręgów społecznych. W swej istocie był on przede wszystkim sporem o istnienie Boga i naturę człowieka. Przyrodnicy i filozofowie skłaniający się ku ateizmowi próbowali bowiem zanegować stwórcze działanie Boga w odniesieniu do gatunku ludzkiego i do dusz poszczególnych osób, a w człowieku skłonni byli widzieć jedynie lepiej rozwinięte zwierzę, powstałe na skutek wyłącznie naturalnych procesów, nie zaś istotę stworzoną na obraz i podobieństwo Boże. W ten sposób w ich doktrynach człowiek stracił nie tylko swoje wyjątkowe miejsce w planach Boga, lecz również szczególną pozycję we wszechświecie. System myślowy Teilharda de Chardin, chociaż jest związany z ewolucjonizmem, prezentuje jednak, po pierwsze - koncepcję ewolucji inną niż klasyczny ewolucjonizm biologiczny typu darwinowskiego, a po drugie - zawiera wiele elementów zaczerpniętych z filozofii i teologii chrześcijańskiej. W jego ujęciu człowiek stoi w centrum kosmicznego procesu ewolucji zbieżnej (nie działającej nigdy na drodze przypadków i zmierzającej do jednego punktu finalnego, czyli zupełnie inaczej niż w koncepcji Darwina, Spencera lub Bergsona) jako oś lub strzała wskazująca na cel ewolucji. Pojawienie się gatunku homo sapiens na Ziemi było szczególnym wydarzeniem w dziejach wszechświata, a ów proces wyłaniania się człowieka $z$ tworzywa kosmicznego francuski jezuita określał mianem antropogenezy. Teilhard uznał fenomen czlowieka za najważniejszy przedmiot swych analiz i twórczości naukowej, gdyż chodzi w nim przecież o nas samych, o prawdę na nasz temat. Jego zachwyt nad człowiekiem wyrażają między innymi takie oto słowa: „Bliskość zjawiska, jakim jest człowiek musi nas, tkwiących wewnątrz, oślepić, skoro nie odczuwamy żywiej, ze jest ono - nawet z czysto fenomenologicznego punktu widzenia - czymś niezwykle osobliwym, szczególnym, jedynym."12 Zdaniem autora „Fenomenu człowieka” antropologia przyrodnicza i filozoficzna często badała gatunek homo sapiens w zbyt wąskim zakresie, gdyż albo nadmiernie podkreślała indywidualność poszczególnych osób, albo nazbyt akcentowała prymat gatunku lub społeczności ludzkiej nad jednostką. Oprócz tego często zdarzało się, iż naukowcy nie dostrzegali głębokich związków procesu antropogenezy z ewolucyjnym rozwojem wszechświata. Dużym błędem było także zbyt-

12 Teilhard de Chardin, Pisma, t. 1. s 13. 
nie koncentrowanie się na sferze materialnej (cielesnej) człowieka i pomijanie bądź niedocenianie jego sfery duchowej (psychicznej). W oparciu o materiał empiryczny, zwłaszcza o rezultaty badań paleoantropologicznych, Teilhard stwierdził, iż człowiek jest najdoskonalszym i wyjątkowym tworem ewolucji na Ziemi. Następnie dokonał on ekstrapolacji procesu ewolucyjnego na całą rzeczywistość i uznał, że człowiek zajmuje w nim szczególne miejsce. Według francuskiego myśliciela, gdyby przedstawić obrazowo rozwijający się wszechświat w postaci stożka, którego podstawę stanowi nieuporządkowana wielość tworzywa kosmicznego, a wierzchołek Bóg - punkt Omega ewolucji, wówczas człowiek stanowiłby oś tej bryły, wskazującą na kierunek owego procesu. Teilhard bardzo gruntownie analizował przebieg antropogenezy, wychodząc w swych rozważaniach od uchwycenia fenomenu życia (nie tylko biologicznego, ale i kosmicznego, gdyż francuski uczony wyznawał jakąś postać panwitalizmu). Człowiek zatem jest według niego najpierw częścią życia i to częścią szczególną, najdoskonalszą. ${ }^{13}$ Zycie jest dostrzegalne dla doświadczenia zmysłowego i staje się obiektem badań naukowych dopiero wtedy, gdy przekroczy pewną wartość poprzez tworzenie się prostych organizmów, które, zdaniem francuskiego uczonego, powstały najpierw w zewnętrznej warstwie młodej Ziemi i były typu białkowego. ${ }^{14} \mathrm{Od}$ pojawienia się życia organicznego uzależniony był natomiast dalszy przebieg procesu ewolucji na naszej planecie, wiodący do powstania człowieka i jego świadomości refleksyjnej. Badając z perspektywy paleoantropologicznej początki gatunku homo sapiens, Teilhard stwierdził, iż zacierają się one bezpowrotnie i na skutek oddziaływania czasu stają się dla naukowców niedostrzegalne. Zanim powstał gatunek ludzki, życie biologiczne posiadało już liczne formy roślinne i zwierzęce oraz osiągało coraz wyższy stopień złożoności i psychizmu. Antropogeneza była więc poprzedzona przez wcześniejsze etapy rozwoju życia i myśli, które ją przygotowały. Najogólniejszy schemat teilhardowski przedstawiał owe etapy jako: przedżycie (zalążki życia w tworzywie kosmicznym), życie (organiczne), myśl (życie ludzkie obdarzone samoświadomością).

Geneza człowieka wiązała się, zdaniem Teilharda, $\mathrm{z}$ rozwojem całego wszechświata, a nie wyłącznie życia ziemskiego. Osobę ludzką należy bowiem rozpatrywać najpierw jako element gatunku, ludzkość jako część ziemskiego życia organicznego, te zaś jako fragment ewoluującej rzeczywistości. Gdy złożoność tworzywa kosmicznego oraz związany z nią rozwój życia przekroczyły określony próg, wówczas dopiero nastąpiła hominizacja, czyli pojawiła się na Ziemi sfera myśli refleksyjnej. Punkt hominizacji według francuskiego jezuity był momentem, w którym nastąpiła równowaga pomiędzy materialną i duchową sferą duchomaterii. Stanowił on również swoiste przesilenie, od którego strona du-

\footnotetext{
13 Por. Teilhard de Chardin, Pisma, t. 1, s. 15.

14 Por. tamże, s. 21.
} 
chowa zaczęła dominować w materialno-duchowym tworzywie wszechświata. Postępując zgodnie z osią stożka, którą stanowi rozwój człowieka, ewolucja przebiegała dalej przede wszystkim w sferze duchowej. Jej tempo stopniowo nabierało przyśpieszenia, gdyż w człowieku stała się ona świadoma samej siebie i przyjęła postać częściowej autoewolucji.

Ludzka samoświadomość ściśle związana była, przypomnijmy, z rozwojem układu nerwowego organizmów, zwłaszcza ich mózgu. Wraz z następowaniem owych procesów na Ziemi pojawiały się kolejno prymitywne formy przedludzkie: prehominidzi, protohominidzi, aż w końcu, pod koniec ery trzeciorzędu, powstał gatunek homo sapiens. Wówczas też psychizm typu zwierzęcego, bezrefleksyjnego przekształcił się w myśl refleksyjną, początkując tworzenie się sfery myśli wspólnej całemu gatunkowi, zwanej przez Teilharda noosferą. Pojawienie się ludzkiej formy myślenia zapoczątkowało zarazem świat osobowy, którego istotnymi atrybutami są: intelekt, wolna wola i zdolność kochania. W osobach ludzkich mamy też do czynienia ze świadomością drugiego stopnia. Francuski myśliciel następująco ją charakteryzował: „Przejście od świadomości jeszcze rozproszonej do świadomości na tyle ześrodkowanej, by mogła stać się sama dla siebie przedmiotem. Człowiek nie jest już tylko istotą, która wie, ale istotą która wie, że wie. Obdarzony jest on świadomością podniesioną do drugiej potęgi." ${ }^{15}$ Teilhard nazywał także ludzką świadomość refleksyjną widzeniem. Jego zdaniem życie polega na tym aby widzieć, czyli poznawać i rozumieć coraz lepiej siebie samego oraz wszechświat. Człowiek znalazł się w takiej sytuacji egzystencjalnej, że musi widzieć, aby móc doskonalić się w procesie antropogenezy. Wraz z pojawieniem się ludzkiej refleksji nastąpił całkowicie nowy jakościowo, szczególny etap w procesie ewolucji kosmicznej. Osoby ludzkie zaczęły bowiem przejawiać inwencję twórczą w myśleniu i działaniu, dzięki czemu uniezależniły się w pewnym stopniu od ewolucji oraz pojawiających się w niej zdarzeń losowych. Teilhard pisał na ten temat: „Istota obdarzona refleksją, wskutek samego zwinięcia się w sobie, staje się od razu zdolna do rozwoju w nowej sferze. W rzeczywistości rodzi się wówczas inny świat. Abstrakcja, logika, racjonalne wybory i wynalazki, matematyka, sztuka, mierzenie przestrzeni i czasu, niepokoje i marzenia miłosne. Wszystkie te przejawy życia wewnętrznego są niczym innym jak „,burzeniem się” nowo utworzonego centrum, które wybucha w głębi siebie." ${ }^{16}$ Pojawienie się gatunku homo sapiens stanowiło zatem przełom i zupełnie nową jakość w procesie ewolucji wszechświata, która odtąd skoncentrowała swój wysiłek głównie na człowieku. Chociaż bowiem gatunek ludzki jest według Teilharda najmłodszy, to jednak wykazuje największą zdolność rozwoju, posiada niebywałą moc ekspansji i wyjątkową ce-

15 Teilhard de Chardin, Pisma, t. 2, s. 278.

16 Teilhard de Chardin, Pisma, t. 4, s. 131. 
chę, jaką stanowi skłonność do łączenia się w społeczności rozumnie kierowane. Także mózg ludzki zmieniał się szybciej niż mózgi zwierząt, osiągając najwyższy stopień zorganizowania i wewnętrznej złożoności. Ogromna jakościowa różnica, którą dostrzega się pomiędzy psychizmem zwierzęcym a ludzkim, skłaniała francuskiego paleontologa do postawienia tezy, iż zmiana ta dokonała się w sposób gwałtowny - skokowo, a nie stopniowo. W opinii Teilharda ów skok mógł dokonać się w wielu miejscach Ziemi równocześnie. Francuski uczony akceptował koncepcję poligenizmu (więcej niż jedno ognisko narodzin gatunku ludzkiego). Jednocześnie był on zwolennikiem monofiletyzmu, czyli popierał pogląd o genezie człowieka z jednego filum biologicznego (większej grupy osobników). Jako przyrodnik a zarazem kapłan katolicki oprócz wyjaśnień czysto naturalistycznych dopuszczał on także elementy filozoficzne i teologiczne w swej koncepcji antropogenezy. $Z$ tego względu jego ewolucjonizm nie negował teorii kreacjonizmu świata i człowieka oraz oficjalnej nauki Kościoła Katolickiego. Teilhard stwierdzał wyraźnie, iż Bóg działa stwórczo poprzez ewolucję, a przekształcenie psychizmu zwierzęcego w świadomość ludzką wymagało pomocy siły nadprzyrodzonej. Nie wykluczał on więc (jednak zarazem jednoznacznie nie potwierdzał), że Bóg odrębnym aktem stwórczym powołuje do istnienia poszczególne dusze ludzkie. Jego zdaniem Stwórca korzystał w procesie kreacji człowieka z tworzywa naturalnego, którym była psychika protohominidów (nie było to zatem stwarzanie z zupełnej nicości). Niektórzy teolodzy katoliccy, na przykład Karl Rahner, głosili taką teorię stwarzania człowieka, nadając jej nazwę kreacjonizmu ewolucyjnego. Według Teilharda każda dusza ludzka jest spodkobierczynią ewolucyjnych sukcesów wypracowanych uprzednio przez zespół wszystkich energii ziemskich. Spotyka ona życie i pojawia się na określonym jego poziomie, a włączona we wszechświat jest przeniknięta falą wpływów kosmicznych, które musi zasymilować i zjednoczyć w sobie. ${ }^{17}$ Do zaistnienia dusz ludzkich (Teilhard po kartezjańsku utożsamiał je wyłącznie z psychizmem człowieka, zwłaszcza z jego myślą refleksyjną) konieczny jest jednak specjalny akt stwórczy Boga. Działanie Boże jest immanentne wobec przyrody i nie pomija ono udziału energii tkwiących w świecie, zwłaszcza energii miłości, przy zaistnieniu dusz, które są łącznym skutkiem owych przyczyn. Francuski myśliciel ujmował genezę duszy ludzkiej także jako mozolne wynurzanie się jej z kosmicznego tworzywa pod przyciągającym działaniem Boga realizowanym na drodze jego stopniowego jednoczenia i interioryzacji. Dusza jawi się więc w teilhardyzmie jako coś, co niejako wyrasta z duchomaterii lub też rodzi się z niej przy współudziale Boga. Tworzywo kosmiczne jest zatem w pewnym stopniu źródłem dusz obdarzonym mocą duchową. O ile w odniesieniu do pojawienia się psychizmu organizmów niższych od człowieka taka koncepcja nie budziła większych zastrzeżeń, o tyle zastosowana

17 Por. Teilhard de Chardin, Pisma, t. 1, s. 306. 
do genezy duszy ludzkiej wzbudziła ona liczne kontrowersje, szczególnie wśród myślicieli chrześcijańskich.

Zdaniem francuskiego jezuity tylko człowiek, z racji posiadania rozumnej duszy, jest w stanie poznawać i rozumieć świat, z którego się wyłonił, oraz swoje w nim miejsce. Może on również pojmować siebie samego i zadanie, jakie ma do spełnienia w kosmosie. W procesie antropogenezy człowiek został wyposażony w swego rodzaju „zmysły” duchowe, które pozwalają mu odkryć jego centralną pozycję w ewoluującym wszechświecie. Teilhard uznał, iż ich stopniowe nabywanie związane było z ,historią walk ducha." Do owych ,zmysłów duchowych” francuski myśliciel zaliczył: zmysł ogromu przestrzeni, która otacza człowieka; zmysł głębi pozwalający poznawczo przebić się człowiekowi poza doznawaną zmysłowo rzeczywistość i dotrzeć do jej duchowej istoty; zmysł liczby, który umożliwia ujęcie wielości elementów wchodzących w przemiany dokonujące się w kosmosie; zmysł jakości, za pomocą którego człowiek zauważa w przyrodzie różne stopnie doskonałości bytów; zmysł ruchu wykrywający rozwój wszechświata pod pozorną jego niezmiennością; zmysł rzeczywistości organicznej, dzięki któremu dostrzega się jedność wszechświata. ${ }^{18}$ Według autora „Fenomenu człowieka” proces antropogenezy doprowadził do takiej sytuacji, w której także w sferze poznawczej człowiek stanowi centrum rzeczywistości, gdyż poznaje on świat całościowo oraz obejmuje go w jego rozwoju ewolucyjnym, czyli prawdziwie. Widzenie rozumiejące i prawdziwe jest przywilejem wyłącznie ludzi, ponieważ zwierzęta potrafią jedynie obserwować świat i instynktownie reagować na bodźce zewnętrzne. Ludzkie poznanie zbiega się z rzeczywistą strukturą świata i odzwierciedla ją w postaci pojęć, twierdzeń, teorii lub systemów naukowych - koherentnych $\mathrm{i}$ interkomunikowalnych. Taka koncepcja prawdy zgodna jest $\mathrm{z}$ klasycznym jej rozumieniem, to znaczy z ujmowaniem prawdy jako zgodności poznania z rzeczą poznawaną (Adaequatio intellectus et rei). Człowiek w doktrynie Teilharda stanowi centrum obserwacji a zarazem konstrukcji wizji wszechświata i również z tego powodu teilhardyzm jest systemem antropocentrycznym.

Inną niezmiernie ważną własnością ludzkiej duszy jest jej zdolność kochania. Według francuskiego jezuity ona także stanowi rezultat procesów ewolucyjnych tworzywa kosmicznego. Koncepcja ta poszerza sens rozumienia miłości, gdyż czyni z niej nie tylko duchową władzę duszy ludzkiej, lecz również pewien rodzaj energii kosmicznej. Francuski myśliciel wyróżnił kilka rodzajów miłości: biologiczno -seksualną, moralno-interpersonalną, społeczną oraz religijno - kosmiczną. Miłość biologiczno-seksualna związana jest z istnieniem pary: mężczyzna - kobieta, których cechy fizyczne i psychiczne dopełniają się. Miłość interpersonalną Teilhard rozważał zawsze w łączności z miłością społeczną, a tę z kolei łączył z miłością religijno - kosmiczną. Pisał on na temat miłości jako podsta-

18 Por. Teilhard de Chardin, Pisma, t. 4, s. 13. 
wowej energii jednoczącej kosmos i ludzkość ze sobą oraz z Bogiem: „Ponieważ wszechświat chrześcijański polega na mocy swej struktury na jednoczeniu się osób elementarnych w osobowości wyższej (Boskiej), więc energią dominującą i finalną całego systemu może być tylko przyciąganie międzyosobowe, czyli miłość. Zatem miłość Boga do świata i do każdego z jego elementów, jak też miłość tych elementów do siebie i do Boga nie są jedynie skutkiem wtórnym, dodanym do procesu stwórczego, ale wyrażają one zarazem jego czynnik sprawczy i podstawowy dynamizm." ${ }^{19}$ Miłość jako najważniejsza forma energii kosmicznej jednoczy wewnętrznie wszechświat i ludzkość. W czasach eschatologicznych spowoduje ona ich zjednoczenie z Bogiem - punktem Omega ewolucji przez pośrednictwo Chrystusa Kosmicznego i przyczyni się do powstania Pleromy, czyli doskonałej rzeczywistości duchowej i osobowej.

Nieśmiertelność człowieka francuski filozof również wyjaśniał w kontekście ewolucyjnej wizji kosmosu oraz procesu antropogenezy. Według niego hominizacja jako szczytowy etap ewolucji tworzywa wszechświata jest faktem nieodwracalnym, a wykluczenie regresu hominizacji (czyli zagłady ludzkich dusz tożsamych z refleksyjną świadomością człowieka) było jednoznaczne z uznaniem jednostkowej, osobowej nieśmiertelności. Gdyby antropogeneza kończyła się unicestwieniem duszy ludzkiej, to byłaby bezsensowna i bezcelowa. Z powyższego poglądu wynikał postulat bytowej nieśmiertelności człowieka, chociaż zdaniem niektórych badaczy myśli teilhardowskiej był to raczej akt osobistej wiary francuskiego filozofa, niż rzeczywista, racjonalna argumentacja. ${ }^{20}$ Teilhard głosił pogląd, że wokół człowieka koncentruje się i zwija cały wszechświat w procesie ewolucyjnego rozwoju, lecz nie wykluczał on, iż mogą istnieć istoty rozumne na innych planetach w kosmosie. ${ }^{21} \mathrm{~W}$ takim wypadku istniałoby kolejno lub równocześnie więcej ośrodków ześrodkowania myśli we wszechświecie. Chociaż człowiek wydaje się obecnie centrum i szczytowym punktem procesu ewolucji kosmicznej, to jednak nie jest on jej etapem ostatecznym. Teilhard twierdził, iż w gatunku ludzkim nadal dokonują się przemiany ewolucyjne, tyle że już na innej niż biologiczna płaszczyźnie. Antropogeneza przestała być bowiem ewolucją biologiczną, a stała się ewolucją społeczną. Człowiek stał się więc świadomym kontynuatorem ewolucji, wziął ją niejako we własne ręce i jest za nią odpowiedzialny. Dalszy przebieg antropogenezy przebiega na płaszczyźnie społecznej i stanowi postać autoewolucji.

19 Teilhard de Chardin, Pisma, t. 2, s. 152.

20 Por. S. KowalczYK, Z refleksji nad człowiekiem. Człowiek-społeczność- wartość, Lublin 1995, s. 75.

${ }_{21}$ Por. Teilhard de Chardin, Pisma, t. 1, s. 90-100. 


\section{Proces socjalizacji, totalizacji i personalizacji ludzkości}

Nauki przyrodnicze i humanistyczne starają się wyjaśniać przede wszystkim przeszłość oraz obecny stan człowieka. W wizji teilhardowskiej najbardziej interesujące są rozważania na temat bliższej i dalszej przyszłości gatunku ludzkiego oraz jej związku z przyszłością całego wszechświata. Pominięcie analiz dotyczących przyszłości zniekształciłoby z pewnością teilhardyzm. Według francuskiego jezuity człowiek jako gatunek charakteryzuje się wielkim dynamizmem rozwoju i potrafi podporządkowywać sobie siły tkwiące w przyrodzie. Ludzkość reprezentuje tę cząstkę rzeczywistości, w której skupiły się najbardziej wartościowe rezultaty ewolucji i dlatego stanowi najaktywniejszą część wszechświata, wyznaczając jego przyszłość jako wszechświata duchowego i personalistycznego. Obecnie gatunek homo sapiens znalazł się w takiej sytuacji, że może w dużym stopniu sam kierować swoim rozwojem, a jego wysiłek w tym względzie stanowi kontynuację procesu ewolucji kosmicznej na poziomie społecznym. Perspektywa przyszłości otwiera zatem przed ludzkością możliwość zjednoczenia się w jeden organizm społeczny - tzw. społeczność uplanetyzowaną. Zdaniem Teilharda zbudowanie takiego globalnego społeczeństwa to tylko kwestia czasu, ponieważ człowiek ze swej natury jest istotą społeczną, skłonną do tworzenia więzi z innymi ludźmi oraz wspólnotami. W ujęciu teilhardowskim owe relacje społeczne są przedłużeniem procesu kosmicznej ewolucji zbieżnej i stanowią jedną z jej egzemplifikacji. Francuski myśliciel dostrzegał celowy charakter procesów społecznych zmierzających do zjednoczenia gatunku ludzkiego w łonie jednej ogólnoplanetarnej społeczności. Jego zdaniem przyszłość ludzkości ma być nacechowana dążeniem do: pełnej prawdy o świecie i człowieku, coraz doskonalszej sprawiedliwości, harmonii w stosunkach międzyludzkich, rozwoju poczucia piękna. ${ }^{22}$ Prawo złożoności-świadomości na etapie życia społecznego ciągle funkcjonuje, chociaż przejawia się w sposób właściwy tylko dla tego poziomu zmian ewolucyjnych. Przypomnijmy, iż pojawienie się gatunku homo sapiens zapoczątkowało nowy etap ewolucji już świadomej siebie, czyli autoewolucji. Pogląd ten przypomina heglowską koncepcję rozwijającego się ducha absolutnego, który w człowieku - jako duch subiektywny - staje się samoświadomy. Teoria ewolucji pełni natomiast w teilhardyzmie rolę analogiczną do heglowskiego ducha absolutnego. Francuski jezuita określał etap autoewolucji gatunku ludzkiego nazwą socjalizacji i rozumiał przez nią stopniowe tworzenie się społeczności uplanetyzowanej, zjednoczonej dzięki miłości oraz poznaniu prawdy, tworzącej sferę wspólnej myśli ludzkiej zwanej noosfera. Koncepcja noosfery także nosi znamiona heglizmu, gdyż zbliżona jest do nauki Hegla o duchu obiektywnym. Autor „Fenomenu człowieka” uważał, iż proces socjalizacji można zasadniczo podzielić na dwa etapy: socjali-

22 Por. N. M. WILDIERs, Ku chrześcijańskiemu neohumanizmowi, Warszawa 1967, s. 72-73. 
zację ekspansji i socjalizację kompresji. Pierwszy z nich polegał na rozpraszaniu się ludzkości w okresie jej wczesnego rozwoju i stopniowym zaludnianiu oraz podporządkowywaniu sobie Ziemi. Gatunek ludzki cechował się wówczas dużym przyrostem naturalnym i tempem rozprzestrzeniania się na wszystkich kontynentach. Teilhard tak oto opisywał ów proces: „Uderzająca zdolność ekspansji, charakterystyczna dla grupy zoologicznej człowieka, jest oczywiście związana z postępem socjalizacji. Ludzkość - najmłodszy twór ewolucji - uzyskawszy dzięki świadomości refleksyjnej zdolność gromadzenia i kojarzenia elementów, które ją tworzą, mogła sobie szybko utorować drogę poprzez biosferę, a nawet poza nią. W tych warunkach zaludnienie Ziemi, oceniane z perspektywy teraźniejszości, musi się przedstawiać jako wynik szeregu coraz silniejszych impulsów, przy czym każdemu takiemu impulsowi odpowiada nowa, lepsza organizacja społeczna." ${ }^{23}$ Proces socjalizacji ekspansji wiązał się również z powstawaniem narodów, grup etnicznych oraz państw. Teilhard porównywał proces socjalizacji do przebiegu południków na kuli ziemskiej, które od jednego bieguna rozbiegają się najpierw ku równikowi, aby po jego przekroczeniu znów zacząć się zbiegać na drugim biegunie. Po przejściu pewnego punktu krytycznego w zaludnianiu Ziemi ludzkość zaczęła się jednoczyć. W opinii francuskiego jezuity nastąpiła wówczas druga faza socjalizacji, czyli socjalizacja kompresji. Wśród czynników przyczyniających się do jednoczenia ludzkości znajdowały się czynniki zewnętrzne, związane ze środowiskiem oraz wewnętrzne, tkwiące w psychice ludzkiej. Do czynników zewnętrznych Teilhard zaliczył ograniczoną powierzchnię kontynentów i kurczące się zasoby bogactw naturalnych. Fakty te zmusiły gatunek ludzki do współpracy i jednoczenia się. Potwierdzają tę opinię następujące słowa francuskiego myśliciela: „Bez wzajemnego nacisku cząsteczek (...) na świecie prawdopodobnie nigdy nie powstałoby życie ani świadomość, a już na pewno nie wytworzyłaby się społeczność ludzka. Skoro więc cywilizacja osiągnęła obecny poziom i obecne tempo rozwoju, czyż nie jest to następstwem pewnego optymalnego stosunku pomiędzy rozmiarami istoty ludzkiej a krzywizną ciała niebieskiego, na którym się znajdujemy?" ${ }^{24}$ Czynnikiem wewnętrznym wpływającym na tempo socjalizacji kompresji był, według francuskiego paleontologa, rozwój ludzkiego psychizmu z jego wyjątkową zdolnością do inwencji twórczej w różnych dziedzinach życia oraz wolnością. Człowiek bowiem jako jedyny spośród znanych nam gatunków istot żywych poznaje prawdę i potrafi ją praktycznie wykorzystać do naukowo-technicznego rozwoju cywilizacji. Okazuje się, iż postęp ten w dużej mierze przyczynia się do scalania ludzkości, a do elementów wspomagających ów proces należą także wynalazki ułatwiające komunikację międzyludzką, zwłaszcza środki masowego przekazu. Co więcej, im bardziej ludzkość rozwija się cywiliza-

23 Teilhard de Chardin, Pisma, t. 1, s. 72-73.

24 Tamże, s. 85. 
cyjnie, tym bardziej wzrasta w niej pęd do zdobywania nowej wiedzy o świecie oraz do wynalazczości. Następuje tu zatem sprzężenie zwrotne pomiędzy jednoczeniem ludzkości a rozwojem naukowo-technicznym. Teilhard sam był naukowcem, stąd w jego poglądach zauważa się tak silne podkreślanie ważnej roli nauki w życiu ludzkim. Kolejnym przejawem wzrostu organizacji społecznej i tworzenia się społeczności globalnej jest swoista przestrzeń wspólnej myśli ludzkiej na powierzchni planety, czyli noosfera. Stanowi ona w koncepcji teilhardowskiej jakąśs postać świadomości zbiorowej i uwidacznia się w ogólnoludzkim charakterze uniwersalnych wartości moralnych, ideałów estetycznych, odkryć naukowych lub wynalazków technicznych. Noosfera posiada charakter kolektywny i rozwija się konwergentnie, czyli zbieżnie, chociaż jej twórcami są poszczególne osoby. Francuski jezuita nie ograniczył się w swoich poglądach do opisu społeczności naturalnych, takich jak wspólnota rodzinna lub państwowa, lecz zapowiadał zjednoczenie gatunku ludzkiego w wymiarze ogólnoświatowym. W jego dziełach trudno jest znaleźć głębsze analizy postaci i roli wspólnot rodzinnych, kościelnych, zawodowych czy państwowych w globalnym społeczeństwie przyszłości i wydaje się, iż nie dostrzegał on ich istotnej funkcji w życiu każdego człowieka. Człowiek $w$ tym systemie jest $w$ pewnym stopniu wyalienowany $z$ owych naturalnych wspólnot i rozpatrywany wyłącznie jako członek ogólnoludzkiej społeczności oraz wszechświata. Koncepcja społeczności uplanetyzowanej i noosfery antycypowała bardzo popularne obecnie poglądy o globalnej wiosce i procesie globalizacji dokonującym się w świecie współczesnym. Według Teilharda rozwój noosfery doprowadzi kiedyś do swoistej ultrahominizacji i ultrapersonalizacji, a ludzkość przeistoczy się w suprahumanum lub ultrahumanum i będzie to rodzaj kolektywnego superorganizmu..$^{25} \mathrm{Nie}$ znaczy to, iż proces ten dokona się szybko i bezboleśnie, będzie on bowiem wymagał wiele czasu do swej pełnej realizacji. Francuski myśliciel określał także ów proces konwergencji gatunku ludzkiego mianem totalizacji, lecz termin ten nie ma nic wspólnego z totalitaryzmem. Oznacza on co prawda zjednoczenie ludzkości w jednym uplanetyzowanym społeczeństwie, lecz dokona się to przy jednoczesnym zachowaniu odrębności kultur narodowych oraz poszczególnych osób. Zdaniem autora „Fenomenu człowieka” prawdziwa jedność, oparta na kosmicznej, scalającej energii miłości, nie zatraca indywidualnego charakteru swych elementów, ale go różnicuje i udoskonala. Francuski jezuita opisał własny ideał Ziemi i przyszłego społeczeństwa globalnego, który na pierwszy rzut oka wydaje się wizją utopijną. Teilhard wierzył jednak głęboko, że w dalekiej przyszłości, w perspektywie kilku milionów lat, jego wizja się urzeczywistni. Ma to być zatem społeczność, w której życie poświęca się nie dla posiadania, lecz dla wiedzy i duchowego rozwoju. Zgodnie z terminologią Gabriela Marcela, postawa „być" powinna przeważać w nim nad „mieć”, a cała

25 Por. Teilhard de Chardin, Pisma, t. 2, s. 307-312. 
zjednoczona ludzkość ma dążyć do osiągnięcia jak największego stopnia humanizmu oraz personalizacji. Według koncepcji francuskiego filozofa powstanie więc kiedyś społeczeństwo globalne rządzone racjonalnie, w którym zminimalizowane zostaną przejawy nieuporządkowania. Charakterystykę tej społeczności w największym skrócie wyraża następujące stwierdzenie Teilharda: „Przypuszczam więc, że cechą charakterystyczną ludzkości - gdy za kilka milionów lat zbliży się ona do stref ,biegunowych" symbolicznej półkuli, w której się skupia - będzie wyższy stan zbiorowej świadomości, nie wyrażający się już poszerzeniem i różnicowaniem obszaru uczuć i myśli, lecz raczej - coraz ściślejszym scalaniem poglądu na świat." ${ }^{26} \mathrm{~W}$ koncepcji procesu totalizacji ludzkości najwięcej obaw wśród badaczy teilhardyzmu budzi ujęcie relacji pomiędzy poszczególnymi osobami ludzkimi a społeczeństwem uplanetyzowanym - zwłaszcza problem, czy owa społeczność nie dokona zjednoczenia przy użyciu siły lub przymusu psychicznego oraz czy zostanie w niej zachowana ludzka wolność. Zdaniem Teilharda nie istnieje taka groźba, ponieważ w miarę coraz większej totalizacji jednostka i kolektyw wzajemnie się umacniają i dopełniają, a im bardziej indywiduum włącza się w tworzenie zjednoczonej społeczności, tym intensywniej się rozwija i personalizuje. Z drugiej strony, im mocniej społeczeństwo globalne opiera się na jednostkach spersonalizowanych (tzn. w pełni rozwiniętych w swej duchowej, osobowej istocie), tym bardziej się ono humanizuje. W doktrynie teilhardowskiej oba te bieguny wzajemnych zależności są nierozdzielne i tak samo ważne. ${ }^{27}$ Teilhard de Chardin ściśle wiązał społeczną totalizację z uprzednią personalizacją jednostek ludzkich. Personalizacja polega natomiast na tym, że człowiek uzyskuje możliwość optymalnego rozwoju, gdy jednoczy się jednocześnie $\mathrm{z}$ innymi ludźmi oraz z centrum osobowym procesu ewolucji, z Najwyższą Osobą, czyli z Bogiem. Proces ten według francuskiego jezuity przebiega $\mathrm{w}$ trzech fazach. Pierwszą z nich stanowi centralizacja osobowa oznaczająca wprowadzenie przez człowieka coraz większej, uporządkowanej jedności w swoje idee, uczucia i postępowanie. Następnie każda osoba jednoczy się z innymi ludźmi, aby móc w pełni rozwijać własną osobowość. W ostatnim etapie personalizacji może zostać osiągnięte zjednoczenie z całą ludzkością, co nie oznacza, iż powstaje wówczas bezosobowa masa ludzka - jest to bowiem wspólnota w pełni dojrzałych osób. Zdaniem Teilharda pojęcie osoba zawiera o wiele bogatszą treść niż jednostka, gdyż implikuje ono oprócz indywidualnego istnienia także rozumność, wolną wolę i zdolność do duchowej miłości. Ostateczne zjednoczenie gatunku ludzkiego dokona się zatem w sposób całkowicie wolny, gdyż dążenie ludzkości do zjednoczenia nie jest wynikiem jakiejś konieczności dziejowej, lecz wynika $\mathrm{z}$ potrzeby wewnętrznej każdego człowieka. ${ }^{28}$ Francuski myśliciel swoją

26 Teilhard de Chardin, Pisma, t. 1, s. 99.

27 Por. Cz. BARTNIK, Teilhardowska wizja dziejów, dz. cyt., s. 32-35.

28 Por. tamże, s. 43. 
wizją przyszłego społeczeństwa globalnego próbował przeciwstawiać się licznym pesymistycznym poglądom na temat przyszłości gatunku ludzkiego. Jego doktryna miała podtrzymywać w ludziach optymizm oraz wolę życia, które pomogą w dalszym rozwoju i stopniowej totalizacji ludzkości. Ostatecznym kresem tego procesu będzie w czasach eschatologicznych zjednoczenie z Bogiem - Omegą, przez pośrednictwo Chrystusa Wszechświata. Naturalistyczna i futurystyczna wizja teilhardowska uzupełniona jest zatem o elementy chrześcijańskiej nauki o Paruzji Chrystusa, Sądzie Ostatecznym oraz Pawłowej koncepcji przebóstwienia całej rzeczywistości w Pleromie.

\section{Punkt Omega i chrystogeneza jako kres procesu antropogenezy i ewolucj i wszechświata}

Wśród znawców teilhardowskiej antropogenezy i jej związku z ewolucją wszechświata najwięcej kontrowersji wzbudziła koncepcja tzw. punktu Omega będącego sprawcą (poruszycielem) oraz ostatecznym celem ewolucji kosmicznej. Sens terminu punkt Omega w pismach Teilharda, pomimo ciągłych prób jego doprecyzowania, nie jest jednoznaczny. Można bowiem wyróżnić dwa jego znaczenia. Pierwsze $z$ nich oznacza cel konwergentnej ewolucji gatunku ludzkiego, zarówno biologicznej, jak i społecznej oraz kres rozwoju noosfery. Drugie znaczenie odnosi się natomiast do Boga lub do Chrystusa (Chrystusa Wszechświata, bądź Kosmicznego), stanowiącego przyczynę sprawczą i celową ewolucji wszechświata oraz ujawniającego się w niej (wyraża się wówczas immanentny aspekt Boga i Jego działania). W koncepcji autora „,Fenomenu człowieka” immanencja Boga wobec świata nie oznacza, iż jest On częścią stale zmieniającej się rzeczywistości, a Jego transcendencja stanowi swoiste dopełnienie Bożej istoty. Bóg jest zatem jednocześnie immanentny i transcendentny wobec świata. W jednym z esejów Teilhard tak oto ujął to zagadnienie: „Wyobrażenie Boga - Budowniczego przeobraża się w wyobrażenie Boga - Poruszyciela ewolucji. Rzecz jasna, musimy strzec atrybutu Jego transcendencji. Gdyby nie istniał przed czasem, czyż mógłby być spełnieniem czasu i wyjściem poza czas? Równocześnie jednak (może i bardziej, gdyż na tym właśnie polega odmienność nowego spojrzenia) musimy zgłębić i wielbić Jego immanencję i radować się nią." ${ }^{29}$ Wszechświat nie mógłby więc rozwijać się i zmierzać ku eschatologicznej jedności, gdyby nie istniał poza czasem i przestrzenią oraz wszelkim stawaniem się rzeczywistości metafizyczny punkt Omega, wyrazający transcendentny aspekt Boga. Francuski jezuita pisał także na ten temat: „,Kiedy wychodząc poza elementy zaczynamy mówić o świadomym Biegunie świata, nie wystarczy powiedzieć, że wyłania się on w procesie

29 Teilhard de Chardin, Pisma, t. 1, s. 273. 
wznoszenia się świadomości: należy dodać, że w tej genezie jest on już jednocześnie wyłoniony. Inaczej nie mógłby ani niczego podporządkowywać sobie, ani niczego utrwalać, czyniąc niezniszczalnym. Jeśliby ze swej natury nie wymykał się czasowi i przestrzeni, które skupia, nie byłby Omegą." ${ }^{30}$ Punkt Omega w znaczeniu kresu, ku któremu zmierza ewolucja, jest więc ujmowany od strony obserwowanych procesów przemian kosmosu i człowieka. Stanowi on wówczas przyszły stan, do którego zdąża ewoluująca ludzkość oraz wszechświat. Omega pojmowana natomiast jako już aktualnie istniejąca rzeczywistość jawi się jako przyczyna sprawcza uzasadniająca sam fakt zbieżnej ewolucji społecznej i kosmicznej. Teilhardowski, transcendentny Absolut istnieje zatem całkowicie niezależnie od wszechświata, jest jego Stwórcą oraz posiada naturę osobową. Jako że Absolut jest realnie istniejącą Osobą, to możliwe jest nawiązanie z Nim relacji miłości przez każdą osobę ludzką. Miłość bowiem wymaga do swego zaistnienia, aby oba kresy jej relacji były osobami. Teilhard w takich oto słowach wyraził swój pogląd w tym względzie: „Miłość, jak już powiedziałem, umiera w kontakcie z tym, co bezosobowe $\mathbf{i}$ anonimowe (...) W miłości, jak w każdym innym rodzaju energii, linie sił muszą się w każdej chwili ograniczać do już istniejącego podłoża. Centrum idealne, centrum wirtualne - nic z tego nie może wystarczyć. Dla noosfery aktualnej i realnej - centrum realne i aktualne. Aby móc w najwyższym stopniu przyciągnąć do siebie, Omega musi być w najwyższym stopniu obecny."31 Inne wypowiedzi francuskiego jezuity wskazują na to, iż Omega to Bóg chrześcijański - Trójca Święta: „Dlatego też istnienie punktu Omega nie ma nic wspólnego z faktem jego nadprzyrodzonego wywyższenia. Działanie łaski $w$ świecie przejawia się natomiast $w$ tym, iż funkcja powszechnego centrum nie przypadła jakiemuś dowolnemu najwyższemu pośrednikowi między Bogiem a światem, lecz że wziął ją na siebie sam Bóg, wprowadzając nas tym samym, in et cum Mundo ( $w$ świecie i razem ze światem), w swą immanencję w łonie Trójcy Świętej."’32 Istnienie kosmicznego ładu oraz życia i myśli w świecie było dla francuskiego poleontologa czymś tajemniczym i domagającym się uzasadnienia we wszechmocy Boga. Jego zdaniem chociaż to siły rozpadu (entropia energii tangencjalnej, zniszczenie i śmierć) są w świecie bardziej dostrzegalne niż sily twórcze (negentropia energii, pojawienie się życia biologicznego), to jednak ich występowanie we wszechświecie świadczy o istnieniu Stwórcy i Opatrzności Bożej (osobowego punktu Omega). Uniwersalna historia wszechświata (kosmogeneza), jak również związana z nią historia ludzkości (antropogeneza), ostatecznie znajdują swoje dopełnienie w chrystogenezie. Francuski jezuita twierdził, iż ewoluujący kosmos stanowi w jakiś tajemniczy sposób część Chrystusa

\footnotetext{
Teilhard de Chardin, Pisma, t. 4, s. 222.

Tamże, s. 221.

32 Teilhard de Chardin, Pisma, t. 1, s. 127.
} 
Wszechświata, jako część Jego Mistycznego Ciała. Francuski filozof następująco wyjaśniał tę trudną do zrozumienia kwestię: ,Zaczątkowe Ciało Chrystusa mieści się w postaciach chleba i wina. Czy Chrystusowi może jednak wystarczyć to zaczątkowe ciało? Na pewno nie.

Skoro bowiem jest przede wszystkim Omegą, czyli powszechną formą wszechświata, może osiągnąć organiczną równowagę i pełnię tylko wówczas, gdy dokona mistycznej asymilacji wszystkiego co Go otacza (...) Gdy więc wypowiadamy słowa: Hoc est Corpus meum (Oto Ciało moje) - hoc oznacza primario chleb, lecz secundario, a więc niejako w drugiej naturalnej fazie, materią sakramentu staje się po prostu świat, w którym rozprzestrzenia się nadludzka obecność Chrystusa Wszechświata, aby Go dopełnić." 33 Chrystus w mistyczny sposób jest więc obecny we wszystkich bytach, a świat istnieje w środowisku Bożym (le Milieu Divin) lub chrystycznym. Środowisko to przenika rzeczywistość coraz głębiej w toku procesu ewolucji, powodując jego spirytualizację (przemianę w ducha) oraz stopniowe jednoczenie. Dzięki wcieleniu Chrystusa w świat dokonało się, zdaniem Teilharda, nie tylko zbawienie człowieka, lecz także uświęcenie tworzywa kosmicznego (wbrew tym, co uznali wszechświat z jego aspektem materialnym za zly ze swej natury). Przez wcielenie Chrystus przejął funkcję punktu Omega ewolucji i stał się jej poruszycielem. Jak stwierdził francuski jezuita: „Skoro Chrystus i Omega - to jedno, Jego organizujące działanie rozciąga się nie tylko na jedną dziedzinę naszego bytu, a mianowicie na dziedzinę związków sakramentalnych i dobrych sprawności. Aby móc nas zjednoczyć ze sobą poprzez najwyższe sfery naszej duszy, musiał roztoczyć opiekę nad naszym rozwojem, nawet w sferze cielesnej. Dlatego też wywiera kierunkujący, formujący wpływ na całą gamę ludzkich prac, uwarunkowań materialnych i ewolucyjnych przemian kosmicznych." ${ }^{34}$ Autor „Fenomenu człowieka” pojmował Chrystusa Wszechświata jednocześnie na sposób mistyczny i częściowo naturalistyczny. Jego poglądy były zbliżone do panteizmu lub panenteizmu. Sam Teilhard akceptował zresztą tzw. monizm chrześcijanski, albo panchrystyczny, polegający na dążeniu do tego, aby „Bóg był wszystkim we wszystkim" (1 Kor.15, 29). Rezultatem takiej postawy jest jak najściślejsze zjednoczenie człowieka z Chrystusem, a w czasach eschatologicznych połączenie się z Nim całej ludzkości i wszechświata oraz utworzenie duchowej Pleromy. W przypadku człowieka owo zjednoczenie nie oznacza jednak rozpłynięcia się w bezosobowym Absolucie, jak ma to miejsce w panteizmach Wschodu, lecz jedność powodowaną przez energię miłości i związaną z nią osobową relację. Francuski myśliciel wykorzystywał w swej wizji te fragmenty listów więziennych świętego Pawła, w których mówił on o kosmicznej funkcji Chrystusa, zwłaszcza o Paruzji i Pleromie. Potwierdzają to słowa samego Teilharda: „Jezus nie byłby

33 Tamże, s. 134- 135.
34 Tamże, s. 129. 
Bogiem św. Pawła ani Bogiem mojego serca, gdybym patrząc na najlichsze, najbardziej materialne Jego stworzenie nie mógł powiedzieć: Nie potrafiłbym tego zrozumieć, ogarnąć myślą, nie potrafiłbym się tym wzruszyć inaczej jak w odniesieniu do Tego, co czyni rzeczywistą i ostatecznie określa naturalną całość, której ta rzecz jest cząstką. Ponieważ Chrystus jest Omegą, wszechświat jest aż do swego materialnego rdzenia fizycznie przepojony wpływem Jego nadludzkiej natury." ${ }^{35}$ Chrystus Wszechświata i Jezus zrodzony z Maryi w Betlejem, historyczna postać, są według francuskiego myśliciela tą samą osobą. Bóg nie mógłby stać się poruszycielem i celem ewolucji kosmicznej oraz antropogenezy, gdyby w Chrystusie nie stał się Bogiem wcielonym i zbawicielem człowieka. Jednocześnie dzieło wybawienia ludzkości od zła i grzechu nie byłoby możliwe bez odnowy całego wszechświata. Odkupienie Boże ma więc według Teilharda wymiar kosmiczny. Skoro Chrystus wcielił się i zmartwychwstał, to znaczy, iż przejął On rzeczywistą funkcję powszechnego Centrum kosmicznej ewolucji zbieżnej. Swoją miłością jednoczy On wewnętrznie cały wszechświat i ludzkość oraz połączy je w czasach ostatecznych z Bogiem Ojcem w Trójcy Świętej.

\section{Zakończenie}

Poglądy Teilharda de Chardin dotyczące człowieka ściśle wiążą się z całością jego wizji ewoluującego wszechświata. Rezultatem tego jest ujmowanie antropologii nie w postaci koncepcji zawężonych do filozofii człowieka, lecz przedstawianie jej jako antropogenezy, czyli procesu powstania i rozwoju gatunku ludzkiego w wyniku ewolucyjnych zmian tworzywa kosmicznego. Francuski jezuita był przyrodnikiem i zapewne z tego powodu zastosował do badania fenomenu ludzkiego metodologię zaczerpniętą z nauk przyrodniczych. Jego analizy antropologiczne zaczynają się od teorii ewolucji biologicznej, która została następnie zontologizowana i ekstrapolowana na cały kosmos oraz na społeczne życie człowieka. Taka metoda posłużyła francuskiemu myślicielowi także do badania początków gatunku homo sapiens i przewidywania jego odległej przyszłości. Wydaje się, że chociaż pragnął on uniknąć w swym systemie myślowym elementów filozofii lub teologii objawionej (chociaż nie teologii naturalnej), to jednak koncepcje metafizyczne, bądź religijne, są często dopełnieniem lub fundamentem jego twierdzeń przyrodniczych, zwłaszcza paleoantropologicznych. Co więcej, Teilhard w swej pracy naukowej stosował również metody przyrodnicze do rozwiązywania zagadnień filozoficzno-teologicznych. Rezultatem takiego zabiegu metodologicznego było m. in. zatarcie różnicy między antropologią jako filozoficzną nauką o człowieku, a kosmologią (lub filozofią przyrody, w szczególności przyrody ożywionej) dotyczącą

35 Tamże, s. 127-128. 
genezy, struktury bytowej i przyszłości wszechświata. Antropologia teilhardowska w postaci antropogenezy została bowiem przedstawiona jako element filozofii przyrody, a ta znalazła swe dopełnienie w czéściowo naturalistycznie pojętej eschatologii i chrystologii. Koncepcje ewolucji zbieżnej wszechświata oraz antropogenezy wzbudziły wśród badaczy teilhardyzmu pewne wątpliwości. Nie wydato im się metodologicznie uprawnione mieszanie metod badawczych lub stosowanie jednej metody do różnych przedmiotów poznania oraz łączenie w jeden system rezultatów nauk przyrodniczych, filozoficznych i teologicznych. Wiele kontrowersji wzbudziły także niektóre szczegółowe elementy teilhardowskiej koncepcji antropogenezy i kosmicznej ewolucji zbieżnej. Wśród nich znalazły się m.in. chrześcijański panteizm w postaci panchrystyzmu, wiara w możliwość jednoczesnego zachodzenia procesów totalizacji i personalizacji ludzkości, przyjęcie istnienia zarodków życia i psychizmu w tworzywie wszechświata uznanym za duchomaterię, czy też problem ewolucyjnego pochodzenia poszczególnych dusz ludzkich oraz całego gatunku ludzkiego. Wątpliwości wzbudziły również naturalistyczne wyjaśnienia niektórych prawd objawionych w Piśmie Świętym. Niekwestionowaną natomiast zasługą Teilharda w dziedzinie antropologii była jego próba pogodzenia teorii kreacjonizmu i ewolucjonizmu. Rezultaty jego starań w tej kwestii nie zostały jednak powszechnie zaakceptowane przez uczonych - przyrodników, ani przez filozofów i teologów chrześcijańskich. Jego teoria antropogenezy ewolucyjnej dla myślicieli chrześcijańskich wydała się bowiem nazbyt naturalistyczna, a dla ewolucjonistów zbyt teologiczna.

\title{
"Anthropogenesis and its connection with the evolution of the universe according to Pierre Teilhard de Chardin"
}

\begin{abstract}
SUMMARY
This paper deals with the connection between the origin of the human race and the evolving universe in the works of Teilhard de Chardin. The French thinker analysed this problem from different points of view: scientific, philosophical and theological, showing its different aspects. The results of his reflections on this topic form a system of thought in which Teilhard tried to explain the mystery of man and the universe. The main concept of this system is the evolution of the whole universe from a material into a spiritual reality. Part of this cosmic evolutionary process is also the origin of the human race (considered by Teilhard as a species of living creatures and only accidentally as individual
\end{abstract}


human beings). Creation of the world and man according to Teilhard is also a continual process in which God uses the natural law of evolution. Man is the best part and the summit of this cosmic process. The human race has been craeted by God as one philum (monophiletism) and not as as a couple (Adam and Eve in the garden of Eden) or many phila (poliphiletism). While creating human souls, God also uses the material elements of the world, sublimating them into spirit. These opinions created many problems for the Catholic Church and were not accepted.

Theilhardian analyses of the future of the universe and mankind are very interesting and inspiring and have been used by many modern thinkers. Teilhard wrote about one global society united by science and technology (globalisation). In the future people will also form one sphere of human spirit, the sphere of common information (noosphere). Eschatologically, the whole universe along with the human race will be united with God as the mover and final cause of the cosmic evolution (its point Alpha and Omega).The end of the history of all created reality will be the transformation into spiritual reality of the Cosmic Christ. Thus anthropogenesis will be fulfilled in cosmogenesis and finally in Christogenesis.

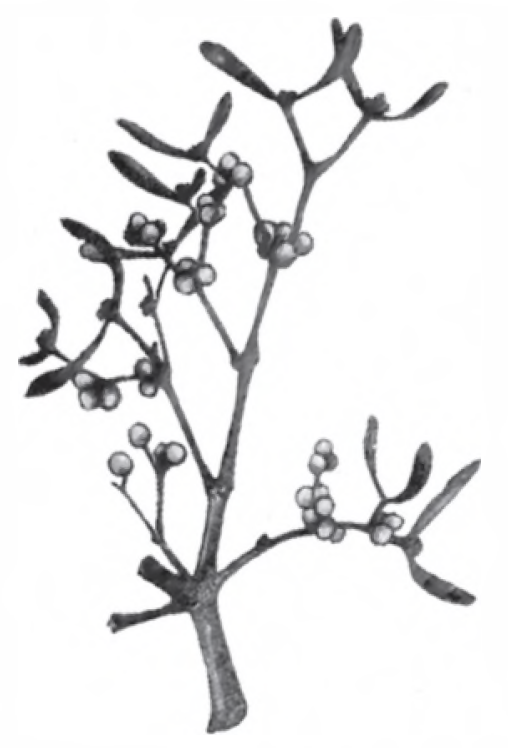

Jemiola pospolita 